\title{
SANCTIONS POLICY IN THE INDONESIAN ACT. NO. 35 OF 2009 ON NARCOTICS
}

\author{
Indah Setyowati \\ indah@unissula.ac.id \\ Sultan Agung Islamic University, Semarang
}

\begin{abstract}
Law is a legitimate product that is issued by the government / state is defined as a rule that should be known by the people or the public anywhere in the territory. The Act of the Republic of Indonesia Number 35 of 2009 on Narcotics is the latest drug laws supersede previous laws. Sanctions policy in this legislation is seen using a double track system which means that the policy of sanctions to use two-lane system is a criminal path for all the prohibited acts and course of action for users / abusers. While the sanctions policy are the following types may be criminal sanctions in principal and additional criminal, criminal sanctions are generally threatened by cumulation ie for example imprisonment with penalty, No weighting towards certain crimes when committed in an organized with conspiracy and carried out by the corporation and recidive. Experiment with a criminal offense the penalty is equal to committing a crime.
\end{abstract}

Keywords: Sanctions Policy; Criminal; Narcotics Act.

\section{A. INTRODUCTION}

Individual matter is basically free in his/her action, but in the action he was constrained by the public. Human society will not allow individual act arbitrarily to the detriment of the community itself. Individual human power is virtually no public face. ${ }^{1}$

$\mathrm{He}$ also explained that in order to protect the interests of the person in society in order to avoid conflict or code there are some social norms to be observed simultaneously sama.Code or norms can be classified as code system with aspects of personal life that includes code or religious norms and morals with the interpersonal aspects of life that includes norms of courtesy or customary and legal norms.

Legal norms are the rules established by the state authorities. The norm is in the form

1 Sudikno Mertokusuma, 1996, "Understanding the Law An Introduction", Liberty, Yogyakarta, p. 2 of regulations in all shapes and types. The purpose of the regulations that are formal in addition to achieving the tertib.aman sosiaal life and also to achieve the objectives of the ideals of the founding of the state, so that the process runs smoothly nation.

Indonesia as a sovereign state upholds the laws formalized and imposed on all members of society indiscriminately, such as the principle that everyone is equal before the law. Similarly, in the Criminal Code which regulates narcotics.

Narcotics are substances or drugs that are beneficial and necessary in the medical world to treat certain diseases. However, if used in accordance with the standard treatment or misused can cause very harmful consequences for the individual or society, especially the younger generation. As a result of the use of narcotics is misused the properties of either physical or psychological 
dependence that adverse effects to the body and mind as well. Rasulullah SAW said "Laa dharara wala dhirara" the purpose of this hadith is should not pose a danger to yourself or others.

Judging from the history of drug legislation that prevention policy against narcotic crime has existed since the Dutch colonial era. This can be evidenced by the legislation narcotics namely Drugs Ordinance (Ordinance Middelen Verdoovende), Stbl. 1927 No. 278 jo. No.536. This Ordinance was later replaced by Act. No. 9 of 1976 On Narcotics which entered into force since July 26, 1976. In the development of the Act No. 9 of 1976 was later replaced by Act. No. 22 of 1997 on Narcotics, hereinafter the latest development in the presence of new types of drugs and involvement of new institutions that had only stipulated in a presidential decree called the National Narcotics Agency (BNN).

Law on narcotics was intended as the sebelumnyayaitu legislation to combat drug abuse and illicit trafficking are very detrimental and endangering the lives of the people, nation and state. In fact the criminal with it dangerous increasingly. According to the UNODC (United Nations Office on Drugs and Crime) drug users (narcotics and dangerous drugs) in Indonesia has reached 5.06 million people, with details of users of crystalline methamphetamine (meth) 1.2 million people, cannabis (marijuana) 2.8 million people, ecstasy and heroin 950 thousand to 110 thousand orang.Dari this amount $52.2 \%$ under the age of 30 years and a group of teenage boys were productive. $^{2}$ From the calculations made by the victim died from drug addiction is currently around 30-40 people a day. For over five months since the

2 Tribune News, October 16, 2015
June-November 2015 figures that the drug addiction rose precipitously from 4.2 million to 5.9 million. $^{3}$

Increasing the number of abusers of course not independent of narcotics in the community carried out by people who are not responsible. Indonesia strategic layout make Indonesia as one of the international drug trade lanes. Narcotics have become one of traded goods because of a benefit that a very large. So, many people who choose to become traffickers and couriers as business land. For instance on January 16, 2016 has been discovered as many as $100 \mathrm{~kg}$ of methamphetamine in a warehouse in Jepara are packed in 194 generators, where the methamphetamine originated in China conducted by the Pakistani group that also involve Indonesia. Indonesia is not only a path of international methamphetamine trade, but also a drug producing country. ${ }^{4}$

Increasing the number of people involved in drug abuse and trafficking of narcotics shows that the process of interaction among community members produce aberrant behavior. Deviant behavior is an action that deviates from the pattern rules or prevailing social norms, including the rule of law.

So to anticipate the surge of drug abuse and trafficking of narcotics need for knowledge of the narcotics law in force in Indonesia, the need for information on crime prevention policy or narcotic crime present in the Act No. 35 of 2009, any action that is not allowed, how the sanctions, etc.

\section{B. DISCUSSION}

The word sanction comes from the Latin "sancire". Sense of the word sancire are

3 Sindo News, 11 November 2015

4 Coverage 6 News, January 28, 2016 
things that are sacred or holy or which result in something protected by the gods so as not to be defiled (sancrosanct). In the subsequent development of the word is given the meaning of "forbidden" which if violated would be subject to punishment. Today the word sanction has two meanings: on the one hand it means is agree to a situation or decision taken, and on the other hand means a means of coercion to implement a particular provision. $^{5}$

In talks on penitentier law, the sanctions meant a means to strengthen the rules, norms, rules, customs, or engagement, so that should not be violated. With the sanctions then a norm will apply such that they are regulated by these norms will be encouraged to behave in accordance with the applicable to him. Therefore it can be said that sanctions will further strengthen the norm, so that its application will be implemented. ${ }^{6}$

An important part of establishing a system of punishment is sanctioned. Its presence will provide direction and consideration of what should be a penalty in a criminal action to enforce a norm. On the other side of punishment itself is the most complex processes in the criminal justice system because it involves a lot of different people and institutions. Criminal Award in abstrakto is set stelsel concerning criminal law sanctions the legislators. While the criminal provision in concreto concerning various bodies all support and implement stelsel the criminal law sanctions. ${ }^{7}$

5 Prof. Dr. H. Loebby Loqman, 2002, "Crime And Punishment", Datacom, Jakarta, p. 6

6 Ibid.

7 Teguh Prasetyo. et al, 2005, "Criminal Law Policy Studies Political Criminalization and Decriminalization", Reader Student: Yogyakarta.
It is undeniable that the issue of criminal sanctions and the action on the stage of formulation of the provisions of the sanctions legislation policy is heavily influenced by drafts or bills that diajaukan to the legislative bodies. The influence that stands out is the diversity of types and forms of sanctions. Determining the type of sanctions, the imposition of criminal and penal implementation is closely linked to the objective of sentencing. Thus any type and form of sanctions to be established, the purpose of punishment should be the benchmark. Therefore there must be similarities pandapat or understanding at this stage of the legislative policy on what the nature or purpose of the criminal sanctions and / or the action itself. ${ }^{8}$

The purpose of punishment is intended as a benchmark for setting a criminal sanction is:

1. Prevent the perpetration of crime by enforcing legal norms for the sake of the community shelter.

2. Popularizing convicted by conducting coaching so as to be good and useful.

3. Resolve conflicts caused by acts of crime, restoring balance and bring a sense of peace in society; and

4. Liberating guilt on the convict. ${ }^{9}$

In the Act. No. 35 of 2009, a policy of sanctions set can be described as follows:

1. Criminal acts with the threat of a minimum of special either imprisonment or fines in the Article 111, Article 112, Article 113, Article 114, Article 115, Article 116, Article 117, Article 118, Article 119, Article 120, Article 121, Article 122 , Article 123,

8 Ibid., p. 85

9 The bill of the Criminal Code, Article 54

SANCTIONS POLICY IN THE INDONESIAN ACT. NO. 35 OF 2009 ON NARCOTICS Indah Setyowati 
Article 124, Article 125. Article 126, Article 129, Article 133, Article 135, Article 13 7, Article 139, Article 140, Article 141, Article 143, Article 147.

\begin{tabular}{|c|c|c|c|}
\hline No. & Article & Jail & Fine \\
\hline 1. & $\begin{array}{ll}\text { Article } & 111 \\
(1) & \\
(2) & \end{array}$ & $\begin{array}{l}\text { 4-12 years } \\
5-20 \text { years }\end{array}$ & $\begin{array}{l}800 \text { million - } \\
8 \text { billion } \\
800 \text { million }- \\
8 \text { billion }+ \\
1 / 3\end{array}$ \\
\hline 2. & $\begin{array}{ll}\text { Article } & 112 \\
(1) & \\
(2) & \end{array}$ & $\begin{array}{l}4-12 \text { years } \\
\text { Lifetime or } \\
50-20 \text { years }\end{array}$ & $\begin{array}{l}800 \text { million - } \\
8 \text { billion } \\
800 \text { million }- \\
8 \text { billion }+ \\
1 / 3\end{array}$ \\
\hline 3. & $\begin{array}{ll}\text { Article } 113 \\
\text { (1) } \\
\text { (2) }\end{array}$ & $\begin{array}{l}5-15 \text { years } \\
\text { The death } \\
\text { penalty, life } \\
\text { or } 5-20 \\
\text { years }\end{array}$ & $\begin{array}{l}1 \text { billion - } 10 \\
\text { billion } \\
1 \text { billion - } 10 \\
\text { billion }+1 / 3\end{array}$ \\
\hline 4. & $\begin{array}{l}\text { Article } 114 \\
\text { (1) } \\
\text { (2) }\end{array}$ & $\begin{array}{l}\text { Lifetime or } \\
5-20 \text { years } \\
\text { The death } \\
\text { penalty, life } \\
\text { stews or 6- } \\
20 \text { years }\end{array}$ & $\begin{array}{l}1 \text { billion - } 10 \\
\text { billion } \\
1 \text { billion - } 10 \\
\text { billion }+1 / 3\end{array}$ \\
\hline 5. & $\begin{array}{ll}\text { Article } & 115 \\
(1) & \\
(2) & \end{array}$ & $\begin{array}{l}4-12 \text { years } \\
\text { Lifetime or } \\
5-20 \text { years }\end{array}$ & $\begin{array}{l}800 \text { million }- \\
8 \text { billion } \\
800 \text { million }- \\
8 \quad \text { billion } \\
+1 / 3\end{array}$ \\
\hline 6. & $\begin{array}{ll}\text { Article } & 116 \\
(1) & \\
(2) & \end{array}$ & $\begin{array}{l}5-15 \text { years } \\
\text { The death } \\
\text { penalty, life } \\
\text { or } 5-20 \\
\text { years }\end{array}$ & $\begin{array}{l}1 \text { billion-10 } \\
\text { billion } \\
1 \text { billion }-10 \\
\text { billion }+1 / 3\end{array}$ \\
\hline 7. & $\begin{array}{ll}\text { Article } & 117 \\
(1) & \\
(2) & \end{array}$ & $\begin{array}{l}3-10 \text { years } \\
5-15 \text { years }\end{array}$ & $\begin{array}{l}600 \text { million - } \\
5 \text { billion } \\
100 \text { million } \\
\text { to } 5 \text { billion }\end{array}$ \\
\hline
\end{tabular}

\begin{tabular}{|c|c|c|c|}
\hline No. & Article & Jail & Fine \\
\hline & & & $+1 / 3$ \\
\hline 8. & $\begin{array}{ll}\text { Article } & 118 \\
\text { (1) } & \\
\text { (2) } & \end{array}$ & $\begin{array}{l}\text { 4-12 years } \\
\text { The death } \\
\text { penalty, life } \\
\text { or } 5-20 \\
\text { years }\end{array}$ & $\begin{array}{l}800 \text { million }- \\
8 \text { billion } \\
800 \text { million }- \\
8 \quad \text { billion } \\
+1 / 3\end{array}$ \\
\hline 9. & $\begin{array}{ll}\text { Article } & 119 \\
(1) & \\
(2) & \end{array}$ & $\begin{array}{l}\text { 4-12 years } \\
\text { The death } \\
\text { penalty, life } \\
\text { or } 5-12 \\
\text { years }\end{array}$ & $\begin{array}{l}800 \text { million }- \\
8 \text { billion } \\
800 \text { million }- \\
8 \quad \text { billion } \\
+1 / 3\end{array}$ \\
\hline 10. & $\begin{array}{ll}\text { Article } & 120 \\
(1) & \\
(2) & \end{array}$ & $\begin{array}{l}3-10 \text { years } \\
5-15 \text { years }\end{array}$ & $\begin{array}{l}600 \text { million - } \\
6 \text { billion } \\
600 \text { million - } \\
6 \quad \text { billion } \\
+1 / 3\end{array}$ \\
\hline 11. & $\begin{array}{ll}\text { Article } & 121 \\
(1) & \\
(2) & \end{array}$ & $\begin{array}{l}\text { 4-12 years } \\
\text { The death } \\
\text { penalty, life } \\
\text { or } \quad 5-12 \\
\text { years }\end{array}$ & $\begin{array}{l}800 \text { million - } \\
8 \text { billion } \\
100 \text { JTA - } 8 \\
\text { billion }+1 / 3\end{array}$ \\
\hline 12. & $\begin{array}{ll}\text { Article } & 122 \\
(1) & \\
(2) & \end{array}$ & $\begin{array}{l}2-7 \text { years } \\
3-10 \text { years }\end{array}$ & $\begin{array}{l}400 \text { million - } \\
3 \text { billion } \\
400 \text { million - } \\
3 \quad \text { billion } \\
+1 / 3\end{array}$ \\
\hline 13. & $\begin{array}{ll}\text { Article } & 123 \\
(1) & \\
(2) & \end{array}$ & $\begin{array}{l}3-10 \text { years } \\
5-15 \text { years }\end{array}$ & $\begin{array}{l}600 \text { million - } \\
5 \text { billion } \\
600 \text { million - } \\
5 \quad \text { billion } \\
+1 / 3\end{array}$ \\
\hline 14. & $\begin{array}{ll}\text { Article } & 124 \\
(1) & \\
(2) & \end{array}$ & $\begin{array}{l}3-10 \text { years } \\
5-15 \text { years }\end{array}$ & $\begin{array}{l}600 \text { million - } \\
5 \text { billion } \\
600 \text { million - } \\
5 \quad \text { billion } \\
+1 / 3\end{array}$ \\
\hline 15. & $\begin{array}{ll}\text { Article } & 125 \\
\text { (1) } & \\
\text { (2) } & \end{array}$ & $\begin{array}{l}2-7 \text { years } \\
3-10 \text { years }\end{array}$ & $\begin{array}{l}400 \text { million - } \\
3 \text { billion } \\
400 \text { million - } \\
3 \quad \text { billion }\end{array}$ \\
\hline
\end{tabular}




\begin{tabular}{|c|c|c|c|}
\hline No. & Article & Jail & Fine \\
\hline & & & $+1 / 3$ \\
\hline 16. & $\begin{array}{l}\text { Article } 126 \\
\text { (1) } \\
\text { (2) }\end{array}$ & $\begin{array}{l}3-10 \text { years } \\
5-15 \text { years }\end{array}$ & $\begin{array}{l}600 \text { million - } \\
5 \text { billion } \\
600 \text { million - } \\
5 \quad \text { billion } \\
+1 / 3\end{array}$ \\
\hline 17. & $\begin{array}{l}\text { Article } 129 \\
\text { (1) }\end{array}$ & 4-20 years & 5 billion \\
\hline 18. & $\begin{array}{l}\text { Article } 133 \\
(1) \\
(2)\end{array}$ & $\begin{array}{l}\text { The death } \\
\text { penalty, life } \\
\text { or } \quad 5-20 \\
\text { years } \\
5-15 \text { years }\end{array}$ & $\begin{array}{l}2 \text { billion - } 20 \\
\text { billion } \\
1 \text { billion - } 10 \\
\text { billion }\end{array}$ \\
\hline 19. & Article 135 & $1-7$ years & $\begin{array}{l}40 \text { million - } \\
400 \text { million }\end{array}$ \\
\hline 20. & $\begin{array}{l}\text { Article } 137 \\
\text { (a) } \\
\text { (B) }\end{array}$ & $\begin{array}{l}5-15 \text { years } \\
3-10 \text { years }\end{array}$ & $\begin{array}{l}1 \text { billion - } 10 \\
\text { billion } \\
500 \text { million - } \\
5 \text { billion }\end{array}$ \\
\hline 21. & Article 139 & $1-10$ years & $\begin{array}{l}100 \text { million - } \\
1 \text { billion }\end{array}$ \\
\hline 22. & $\begin{array}{l}\text { Article } 140 \\
\text { (1) } \\
\text { (2) }\end{array}$ & $\begin{array}{l}1-10 \text { years } \\
1-10 \text { years }\end{array}$ & $\begin{array}{l}100 \text { million - } \\
1 \text { billion } \\
100 \text { million - } \\
1 \text { billion }\end{array}$ \\
\hline 23. & Article 141 & $1-10$ years & $\begin{array}{l}100 \text { JTA - } 1 \\
\text { billion }\end{array}$ \\
\hline 24. & Article 143 & $1-10$ years & $\begin{array}{l}60 \text { million - } \\
600 \text { million }\end{array}$ \\
\hline 25. & Article 145 & $1-10$ years & $\begin{array}{l}100 \text { million - } \\
1 \text { billion }\end{array}$ \\
\hline
\end{tabular}

2. "Article 128" : 6 months imprisonment or a fine Rp.1.000.000,00

3. "Article 130" (1) a. Corporate Executive Board: imprisonment and fined in accordance with the criminal offenses committed (see table)

b. Corporate: Criminal fines by weighting three (3) times the penalty clause being violated.

(2) Criminal additional :

- revocation of business licenses and / or

- Revocation of legal status

4. "Article 131" : Criminal threat than 1 (one) year or a maximum fine of $\mathrm{Rp}$ $50,000,000.00 \quad$ (fifty million rupiah)

5. "Article 132" (1) Or conspiracy trial of a criminal act Article $111 \mathrm{~s} / \mathrm{d}$ of Article 126, Article 129 criminal threat equal to the provisions referred to in the aforementioned articles.

(2) If the criminal offense as of paragraph (1) is now organized criminal threat as in the aforementioned articles of $1 / 3$ (one third)

6. "Article 134" (1) Imprisonment of 6 (six) months or a 
maximum fine of $\mathrm{Rp}$. $2,000,000.00$

(2) Imprisonment of 3 (three) months or a fine of not more Rp.1.000.000,00

7. "Article 138" : Maximum imprisonment of seven years and a maximum fine of 500 million (Rp. $500,000,000.00$ )

8. "Article 142" : Maximum imprisonment of seven years and a maximum fine of 500 million (Rp. $500,000,000.00$ )

9. "Article 144" : For maximum criminal recidive $1 / 3$

10."Article 145" : Committed the crime of drugs and / or precursors of narcotic outside Indonesia are treated the provisions of this law.

11."Article 145" (1) The expulsion of foreign nationals out of Indonesia after a sentence.

(2) After being expelled barred from returning to Indonesia.

By paying attention to the types of sanctions that is written in the articles on narcotics law is seen that the sanctions listed included: the death penalty, imprisonment, imprisonment and criminal fines. Also any additional criminal penalties for corporations that committed the crime of which revocation of a business license and / or revocation of legal status. Both types of these sanctions is classified into basic types of criminal sanctions and additional penalty.

By paying attention to the policy of sanctions in the legislation of narcotics is obvious that the threat of sanctions for most acts that are criminalized are "cumulative" means to add, for example, as an example Article 111 to Article 127, where the sanctions in the form of death, imprisonment and fined.

For more details about the criminal penal need to know about the differences between each other, whereby the difference - the difference is as follows:

1. Death Penalty

The death penalty is the kind of criminal who robs a legal interest ("rectsbelang"), namely the human lives. To impose the death penalty needs to be attention to the terms as follows:

a. The death penalty should be imposed only in cases where the public interest actually threatened (as a crime against state security, rebellion, and so on).

b. The death penalty can only be imposed if absolutely convinced of the guilt of the accused and verifiable as complete.

c. Threatened the death penalty should be an alternative to other types of crime, which means the judge can choose which one he believed more in line with the guilt of the accused can be proven.

From what has been stated above, we conclude that somehow the situation regarding capital punishment is none other than "emergency law (noodrecht)". ${ }^{10}$

10 Hermien Hadiati Koeswadji, 1995, "Development of Various Kinds of Crime in the Framework of Criminal 
At the sentencing, if sentenced to death, the execution verdict until the president gives "fiat execution". Regarding this criminal should be given chance to president to grant pardons and clemency is always possible, although people sentenced to death it was decided to not use the rights available to him clemency in a predetermined time. And often enough the Head of State also gave clemency to the condemned. If imprisonment verdict was upheld by the president so that the decision can be executed, even this decision may also be delayed. ${ }^{11}$

2. Prisoning

The criminal type is the kind of criminal deprivation of an individual's personal liberty condemned. Here is said to appropriation because the inmate is placed in the Penitentiary which resulted in he can not move freely and freely as outside Penitentiary. Imprisonment in the known existence of "the General Strafminima" that limits the minimum punishment or a criminal of the lowest and "the General Strafmaxima" that limit the maximum punishment.

3. Criminal Cage

The same kind of punishment with imprisonment which is depriving liberty that puts others convicted in the Penitentiary but this type of crime is lighter than imprisonment because of the nature of the goal just to scary. An important difference between imprisonment and imprisonment are:

Law Development", PT.Citra Aditya Bakti, Bandung, p. 23

11 Ruslan Saleh, 1983, "Criminal Stelsel Indonesia" , New Literacy, Jakarta, p. 21
- One, that people who are subject to imprisonment can be moved anywhere to undergo criminal, while undergoing imprisonment with no consent can not be moved out of the area where he resided at the time he was sentenced.

- Second, the work assigned to him a lighter required.

- Thirdly, the right person convicted of confinement to remedy the situation on their own, often referred to as a right Pistole. ${ }^{12}$

4. Criminal Fines

Fines are liability a person who has been sentenced to fines by the court (judge) to pay a certain amount of money because he had committed an act can be imprisoned. Thus the penalty is criminal property ( "vermogenstraf") is a criminal, addressed to the wealth of a convict. If a convicted criminal can not meet these fines can be replaced with imprisonment and siorang must undergo "a substitute for imprisonment (fines)". ${ }^{13}$

Provisions for additional criminal punishment is different from the basic criminal provisions. The provisions in question are:

1. Additional penalty can only be imposed in addition to the principal criminal, meaning additional penalty should not be imposed as a punishment only.

2. Additional penalty can only be imposed if the action in the formulation of a criminal act expressly states as a threat. This means that no additional penalty threatened to every type of crime,

12 Ibid., p.24

${ }^{13}$ Hermien Hadiati Koeswadji, Op.cit, p.31 
but only threatened to some specific criminal acts.

3. Although threatened, explicitly in the formulation of a specific criminal act but additional criminal nature facultative meaning left to the judge to drop it or not.

In the Act. No. 35 Year 2009 on Narcotics, the policy of sanctions has been described above also shows similarities with the policy of sanctions in the general provisions of the Criminal Code that is the Criminal staple that includes the death penalty, imprisonment, imprisonment and criminal fines and any additional penalty which pencabutaan business licenses and / or revocation of legal status.

As the criminal acts that have special properties or lex specialists then made their own arrangements to criminal sanctions, does not follow in the Criminal Code. Such as the General strafminima or criminal lowest limit mentioned in the articles themselves, as well as the General strafmaxima. In addition there is also a penalty at the lowest and highest limits set forth in the respective chapters.

$\begin{aligned} \text { Article 54 : } & \text { Drug addicts and victims } \\ & \text { of drug abuse required } \\ & \text { to undergo medical } \\ & \text { rehabilitation and social } \\ & \text { rehabilitation }\end{aligned}$

Article 56 (1): Medical rehabilitation of drug addicts in hospitals designated by the minister.

(2) : Certain disrlenggarakan rehabilitation institution by a government agency or community can do medical rehabilitation of addicts after approval by ministers.

Article 57 : In addition through medication and / or medical rehabilitation, healing drug addicts can be held by a government agency or community through religious and traditional approaches.

Article 58 : Social rehabilitation of former drug addicts held either by the government or by society.

Article 59 (1): Implementation of the provisions referred to in Article 56 and Article 57 is regulated by the Minister.

(2) : Implementation of the provisions referred to in Article 58 shall be regulated by rules minister who held government affairs in the social sphere.

With attention to Article 4 concerning the purpose of the issuance of this law prove that rehabilitation is one of the objectives to be achieved, as stated in the articles that have been outlined above. Similarly, those mentioned in "Article 103" where the judge is authorized to provide rehabilitation verdict.

In the setting of the drug addicts government has also issued Government Regulation No. 25 of 2011 on the Implementation of Mandatory Report Addicts Narcotics where the "Article 13 (3)" stated that drug addicts who are undergoing a judicial process can be placed in a medical 
rehabilitation institution and / or social rehabilitation, Furthermore, in paragraph (4) stated that the placement of the institute of medical rehabilitation and / or social rehabilitation for drug addicts who are undergoing the process of justice is the authority of the investigator, prosecutor or judge in accordance with the examination level after getting a recommendation from a team of doctors.

Other than that realized also their collective agreement through the Joint Regulation of the Chief Justice, the Minister of Law and Human Rights, the Minister of Health, Minister of Social Affairs, the Attorney General, the Chief of Police, Head of the National Narcotics Agency No. 01 / NT / MA / III / 2014, No. 03 of 2014, No. 11 of 2014, No. PER-005 / A / JA / 03/2014, No. 1 of 2014, the joint regulation / 01 / III / 2014 / BNN on Narcotic addict Treatment and Abuse of Narcotics to the Rehabilitation Institute. Thus the drug addicts are no longer geared sanctions padaa imprisonment but comes down in rehab for an agreed sanctions for addict rehabilitation.

\section{CONCLUSION}

The sanctions policy in Act. No.35 of 2009 on Narcotics are the type sanction of criminal principal (capital punishment, imprisonment in a certain time / lifetime imprisonment, criminal fines), additional criminal (revocation of business license and / or revocation of legal status) and action (medical rehabilitation, social rehabilitation, expulsion foreign).

a. Criminal sanctions in general (mostly) cumulatively particularly threatened imprisonment and criminal fines.

b. The number or length of criminal varied, to imprisonment of between one (1) year up to twenty (20) years and for life, fined between 40 million to 10 billion rupiah. Imprisonment of between three (3) months to six (6) months or replaced fined between one million to two million.

c. For certain crimes threatened with minimal special criminal (imprisonment and criminal fines).

d. Their criminal weighting of the offenses were committed in an organized, preceded by consensus, committed by a corporation, and if there is repetition (recidive).

e. Trial or conspiracy to commit a criminal offense shall be punished as a criminal offense.

\section{BIBLIOGRAPHY}

Adi Kusno, 2010, the Criminal Policy in Combating Crime Narcotics by the Children, Malang, UMM.

Darda Nawawi Arif, 2016, Anthology of Criminal Law Policy, Kencana, Semarang.

Hermien Hadiati Koeswadji, 1995, Development of Various Kinds of Crime in the Framework of Criminal Law Development, PT.Citra Aditya Bakti, Bandung. 
Loebby Loqman, 2002, Crime And Punishment, Datacom, Jakarta.

Ruslan Saleh, 1983, Criminal Stelsel of Indonesia, New Script, Jakarta.

Soerjono Soekanto, 2002, the Law and Implementation Effectiveness of Sanctions, CV Ramadja, Bandung,

Sudikno Mertokusuma, 1996, "An Introduction of Law", Liberty, Yogyakarta.

Teguh Prasetyo. et al. 2005. The Criminal Law Policy Studies Political Criminalization and Decriminalization, Pustaka Pelajar, Yogyakarta.

Act. No. 35 of 2009 on Narcotics

The Design of the Code of Penal (Criminal Code draft)

Coverage 6 News, January 28, 2016

Tribune News, October 16, 2015

Sindo News, 11 November 2015 